\title{
WILEY

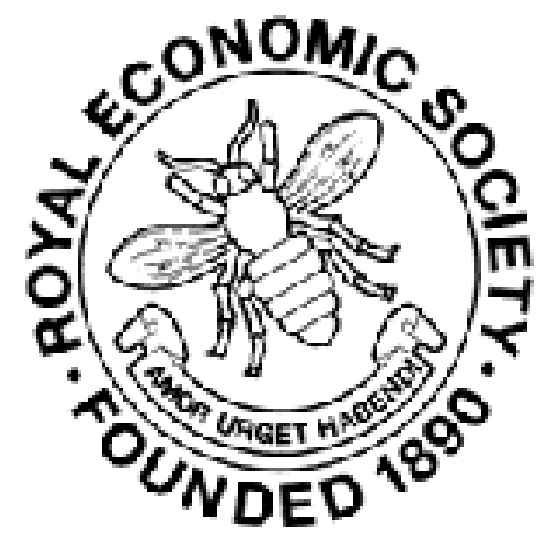

The Plain Facts as to the Trusts and the Tariff, with Chapters on the Railway Problem and Municipal Monopolies. by George L. Bolen

Review by: L. L. Price

The Economic Journal, Vol. 13, No. 49 (Mar., 1903), pp. 71-73

Published by: Wiley on behalf of the Royal Economic Society

Stable URL: http://www.jstor.org/stable/2956868

Accessed: 15/01/2015 08:49

Your use of the JSTOR archive indicates your acceptance of the Terms \& Conditions of Use, available at http://www.jstor.org/page/info/about/policies/terms.jsp

JSTOR is a not-for-profit service that helps scholars, researchers, and students discover, use, and build upon a wide range of content in a trusted digital archive. We use information technology and tools to increase productivity and facilitate new forms of scholarship. For more information about JSTOR, please contact support@jstor.org.

Wiley and Royal Economic Society are collaborating with JSTOR to digitize, preserve and extend access to The Economic Journal. 
such ideas" (as those of "preferential arrangements with the colonies") "altogether, however much we may dislike them?" "The answer to this last question" (of the mother country standing out on "free trade grounds" against "retaliation" "against the measures of foreign governments, which contribute to ruin some of our sugar-producing colonies by means of bounties"), "has already been given by the Sugar Convention of Brussels and the general approval it has received." "Protection or no protection, a feeling is growing up that foreign subsidies, and similar hostile attacks on our shipping, must be met by adequate measures of retaliation, including, if necessary, the cancelling of the repeal of the Navigation Laws." "It is at least fair to admit that for political reasons a great deal may be done which could not receive approval if economic matters and reasoning were alone concerned." These ipsissima verba are surely significant; and this fresh edition of a noteworthy book would be specially noteworthy if it contained them alone. They require no further comment than the remark that, for good or for evil, we have moved a long distance away from the position prevailing in Lord Farrer's time. The near future promises to be fraught with events in the political sphere of engrossing interest to the economic student. We do not think that it will prove so easy to preserve the distinction drawn by Sir Robert between political and economic considerations. $\quad$ L. L. PrICE

\section{The Plain Facts as to the Trusts and the Tariff, with Chapters} on the Railway Problem and Municipal Monopolies. By George L. Bolen. Crown 8vo. Pp. vi-451. (New York: The Macmillan Co. 1902.)

IT would be impossible to question either the meritorious character or the important nature of the attempt avowedly made in this book. It is, as expressed by the author in his Preface, to "gather up, and convey to the general reader, busy with every-day affairs, a considerable amount of that deeper economic and political knowledge which is usually confined to men of special education or experience." Nor for the class of American readers, for whom the book is thus intended, could there, we imagine, be two subjects of keener or more present interest than those handled here. They have of late frequently been joined together in popular discussion; they have derived especial prominence from recent notable speeches of $\mathrm{Mr}$. Roosevelt himself. In Mr. Bolen's hands, however, it is not their connection, on which observers on this side of the Atlantic have been wont to lay no little stress, which receives special attention. The two topics are, on the contrary, discussed in separate sections. By English readers, who pretend to more acquaintance with economic theory than those for whose edification the book is primarily devised, the first of the two sections, dealing with Trusts, will probably be found more interesting 
and instructive than the somewhat trite and obvious remarks upon the Tariff contained in the second section. Mr. Bolen does not, it should be noted, profess to be impartial. "Both sides of a question" are indeed "presented" in his pages; "but only so far as the truth seems to demand, not with effort to say as much for one side as for the other." The cynic will perhaps observe that the limitation thus imposed is likely to prove more influential than the "truth" presented under these conditions. That limit obviously will depend on an arbitrary discretion which will be more or less than human if it exhibits no distorting bias. This is certainly not the case with the argument on the Tariff. Mr. Bolen is a convinced Free Trader, and, with the ardour of assured conviction, he has no doubt that his country will adopt the policy he approves and recommends. For this reason experts will hardly expect to discover very novel reasoning in his pages; and the unreasonable expectation would be disappointed if it were entertained. He states with force the usual arguments advanced by supporters of Free Trade. He exposes with cogency the common fallacies fondly cherished by Protectionists. But those, who think that the question of Free Trade and Protection needs to-day to be considered and stated afresh in the changed circumstances of the times, will find scarcely anything in his book with which they are not already familiar. The discussion of Trusts is more illuminating because the subject itself is newer, and the phenomena considered are as yet comparatively fresh. Mr. Bolen is, we think, also more successful here in presenting "both sides of the question." He sees, for example, possibilities for good as well as for evil in the appearance and activity of Trusts. He holds, indeed, that the most effective remedy for their excesses is the abolition of the secret discrimination given in America in the matter of freights or railway charges. He passes an independent judgment on the chief arguments advanced in the authoritative literature on the subject, with which he shows an exact and wide acquaintance. For instance, he pertinently questions the validity of the common contention that waste in competition affords an opportunity, dexterously seized, for the economies, which can be effected by means of the concentration possible with monopoly. In short, the whole discussion, although it necessarily reproduces much that is known to readers of certain monographs on the subject, which have recently appeared, is characterised by an agreeable freshness of treatment and a stimulating and vigorous independence of thought. We confess, however, to a doubt whether either in this section on Trusts or in that on the Tariff the facts will seem entirely "plain" to the ordinary reader. Mr. Bolen has tried to compress as much information as he possibly can into the limits he has set himself without occasioning confusion; but, as a consequence, he has relieved his text only by overburdening his notes. He has not avoided discursiveness. $\mathrm{He}$ has not attained to a clear consecutive enunciation of the points on which he insists. Nor, while abstaining from the technical phrase- 
ology of economic treatises, has he escaped the use of terms, which may possibly be familiar to business experts, but are hardly intelligible to "plain" citizens. Yet his book is both interesting and forcible. It may not convince his American readers; but it supplies Englishmen with one effective means of following the general drift of shrewd informed American opinion on subjects of pressing importance to others than the inhabitants of the States alone.

L. L. Price

\section{Financial Crises and Periods of Industrial and Commercial} Depression. By Theodore E. Burton. (London: Effingham Wilson. Pp. 392. 1902.)

THIs volume is evidently the fruit of considerable study. Besides providing a useful bibliography, compiled by Mr. Hugh Williams, of the Library of Congress, it brings together in one appendix a number of statistical tables, and in arother a "selection of opinions, culled from many quarter, as to the Causes of Crises and Depressions." Mr. Burton knows his authorities, and quotes from them freely in the course of a painstaking survey of the various problems connected with commercial and industrial fluctuations. But while his work will certainly be useful to some classes of students, there seems to be something lacking when we try to estimate its value as a contribution to economic thought. There is much admirably clear exposition, particularly in the discussion of definitions in the first chapter. But the author's general treatment of his problem gives the impression of breadth rather than of great depth, and one is tempted to speak of his work as a careful investigation of a particular problem, without, perhaps, sufficient reference to the central positions of economic science. This impression is strengthened by an occasional slip in general theory, as on pages 153 and 169, and by the stress laid upon Mill's "fundamental propositions concerning Capital."

So far as it goes, however, Mr. Burton's volume has much to commend it, not least among its merits being its great readability-a merit, by the way, which seems only once to be marred (p. 30) by that bane of economic writings, the "split infinitive." The author properly begins with definitions, distinguishing crises as brief, acute disturbances, "whose storm centre is among the banks and financial institutions," from depressions which last longer, and are predominantly "industrial or commercial." He points out that with the improvement of banking methods and so forth, the crisis is becoming a less conspicuous feature of the credit cycle than it used to be, but that, on the other hand, the closer relations which are growing up between different countries have a strong tendency to make depressions infectious. He discusses the phenomena, and indications of these periods of waning prosperity, and shows how sometimes they do, and sometimes they do not, culminate in a sharp reaction. In this inquiry he lays 